\title{
Reliable knowledge, true freedom: The remnant of the analogia temporalis in the theology of Robert Jenson and its implications for the epistemology-freedom debate
}

\author{
Alexander D. Garton* \\ Faculty of Divinity, West Road, Cambridge, UK \\ *Corresponding author. E-mail: alexandergarton@outlook.com
}

\begin{abstract}
While Karl Barth balances the reliability of revelation with divine counterfactual freedom through the analogia temporalis, Robert Jenson rejects this form of analogy, arguing that it posits an unknowable reality of God behind revelation. He instead transposes metaphysics into narratological terms, arguing that this secures the reliability of revelation and divine freedom, since it means God is future to (and so undetermined by) events in time. This metric for divine freedom cannot, however, replace counterfactual possibility; hence, the analogia temporalis (presupposed in counterfactuals) re-emerges in Jenson's theology. This form of analogy is essential in balancing the reliability of revelation with divine freedom.
\end{abstract}

Keywords: analogia temporalis; Karl Barth; divine freedom; epistemology; Robert Jenson; ontology

The question of how to balance two fundamental tenets of the Christian faith - that revelation discloses God as he truly is, and that the divine acts that form the content of this revelation were undertaken freely - is a matter of fierce debate, ${ }^{1}$ which, as Robert Jenson puts it, 'has recurred throughout history'. ${ }^{2}$ Karl Rahner's famous identification of the immanent and economic Trinities has catalysed a new wave of this debate, with his critique of the ontological distinction between God's eternal triune being and God's triune history in time prompting concern that such an identification of God with history risks rendering God dependent on creation. Yet the same basic point of dispute has arisen 'between Alexandria ... and Antioch, East and West, Lutheran and Reformed'. ${ }^{3}$

Among the countless works written in an attempt resolve the stalemate in which the epistemology-freedom debate has found itself, Jenson's own solution stands apart as one of the most daringly innovative of the twentieth century. Recognising the full

\footnotetext{
${ }^{1}$ This debate shall henceforth be referred to as 'the epistemology-freedom debate'.

${ }^{2}$ Robert W. Jenson, 'God's Time, our Time: An Interview with Robert W. Jenson', The Christian Century 123/9 (2006), p. 33.

${ }^{3}$ Ibid.

(c) The Author(s), 2020. Published by Cambridge University Press. This is an Open Access article, distributed under the terms of the Creative Commons Attribution licence (http://creativecommons.org/licenses/by/4.0/), which permits unrestricted re-use, distribution, and reproduction in any medium, provided the original work is properly cited.
} 
gravity of the epistemological concern, Jenson completely eschews natural theology to preclude the Feuerbachian critique that religion is nothing more than idolatrous selfprojection and instead identifies biblical revelation as the sole source of divine knowledge. Consequently, he regards the task of establishing the absolute reliability of this source (namely, that the Bible describes God as God truly is) as basic to theology. For Jenson, any gap allowed between God and revelation would inevitably correlate to an epistemologically unattainable 'truer reality' of God that threatens to reduce everything built upon this source, including the most fundamental Christian doctrines, to statements merely about the form of God's relation to creation. ${ }^{4}$ The result is a rare example of a systematic theology genuinely dictated by epistemological principles. Yet, Jenson's true contribution to this perennial Christian debate is his application of narratological metaphysics to combine the two facets of the debate themselves: to construct an argument in which the assertion of biblical revelation's reliability simultaneously secures the freedom of God from creation.

Jenson's argument to ensure the reliability of christological revelation borrows heavily from the work of Karl Barth, whose own solution to this problem takes the form of the doctrine of election. Barth argues that God is his event of decision in election, meaning that the revelation of the content of this decision constitutes the revelation of God's very nature, behind which he cannot be considered. According to Barth, God has chosen Christ to be his reality, meaning christological revelation constitutes reliable knowledge of the divine ontology. ${ }^{5}$

For Jenson, however, Barth's location of this decision in 'eternity' (namely, primordial time prior to creation), with revelation as its temporal unfolding, constitutes the covert redeployment of the Platonic analogy of eternity as the archetype of time (namely, the time of revelation), which Barth himself rejects in his Römerbrief as natural theology inapplicable to the Christian faith. ${ }^{6}$ Such an analogia temporalis operates by positing a reality of God in se that is conceptually distinct from the God of revelation and asserting the epistemological value of revelation by its ability to reflect that reality (namely, the eternity where God's being is actually constituted). By Jenson's reckoning, revelation is in this way reduced to a mere shadow of something more primary, implying a deeper, unknowable reality of God behind or beyond it. ${ }^{7}$ This is most clearly seen with regards to the second person of the Trinity, who in Barth's theology exists prior to the incarnation in the extra-revelatory form of the Logos asarkos - a form which, according to Jenson, can accordingly be abstracted from the historical Jesus of Nazareth as the true reality of this divine person.

Making a conscious break from the theology of the Church Dogmatics, therefore, Jenson shuns all use of the analogia temporalis in mediating knowledge of God, arguing that any attempt to transcend the temporal biblical story to find the 'real' God behind it in eternity means 'declaring the story simply to be false. ${ }^{8}$ He thus emphasises as

\footnotetext{
${ }^{4}$ Robert W. Jenson, The Triune God, vol. 1 of Systematic Theology [hereafter ST 1] (Oxford: OUP, 1997), pp. 57-60.

${ }^{5}$ Karl Barth, Die Kirchliche Dogmatik II/2 (Zurich: Evangelischer Verlag A. G. Zollikon, 1942), pp. 3-6, 25.

${ }^{6}$ See Plato, Timaeus 37D, in Plato: Timaeus and Critias, trans. A. E. Taylor (London: Methuen, 1929).

${ }^{7}$ Robert Jenson, God After God: The God of the Past and the God of the Future, Seen in the Work of Karl Barth (Indianapolis: Bobbs-Merrill, 1969), pp. 153-5; Scott R. Swain, The God of the Gospel: Robert Jenson's Trinitarian Theology (Westmont, IL: InterVarsity, 2013), pp. 65-6.

${ }^{8}$ Robert W. Jenson, 'Does God have Time?', in Essays in Theology of Culture (Grand Rapids, MI: William B. Eerdmans, 1995), p. 192.
} 
'central' to his own systematic theology 'that the gospel does not tell of work done by a God antecedently and otherwise determined, but itself determines who and what God is. ' . Jenson's solution is to relocate God's self-determining decision from primal to biblical history, and so to identify it with the event of revelation itself, defining it as the event of the resurrection and consequently defining God as the one who raised the Lord Jesus'. ${ }^{10}$ Likewise, rather than identifying the second person of the Trinity as the eternal Logos, with the historical Jesus merely as his reflection, Jenson identifies him without remainder as 'the human person of the Gospels'. ${ }^{11}$ Accordingly, rather than defining the Son by eternal procession from the Father, Jenson defines him by the resurrection, appealing to Paul's claim in Romans 1:4-5 that Jesus is 'determined [as] God's Son ... from the resurrection of the dead'. Jenson thus argues that to be the Son is simply to be the one who is resurrected. ${ }^{12}$

\section{The reliability of christological revelation}

Having thus described Jenson's basic methodological principle, the article shall now turn to illustrate how he understands God to be self-determined by the resurrection, such that this event does not merely reveal God's identity, but actually determines it. Jenson's reasoning is that the 'Crucifixion put it to the Father' whether he would accept 'this candidate [Jesus] to be his own self-identifying Word' and so be a God who hosts publicans and sinners, and justifies the ungodly. ${ }^{13}$ The resurrection constitutes the Father's acceptance of Jesus and, by extension, the determination of his identity as the God revealed by Jesus. ${ }^{14}$ Thus, God is known by us in the very same way he knows himself, namely in the mutual triune life, since this triune life is none other than the economy of salvation narrated in the gospel. The believer accordingly knows God in that God graciously takes him 'into his own knowledge of himself, meaning by definition that there can be no more ultimate knowledge behind this revelation. ${ }^{15}$ Further, since Jesus is without mitigation the identity of the second divine person, his 'human action and presence is without mitigation God's action and presence'. ${ }^{16}$ As such, Jenson argues that, since Jesus' obedience to death on the cross has concretised his character once and for all as for-us, his (and thus God's) relationship to humanity will always conform to this character, meaning that God's revelatory identification is concrete and reliable. ${ }^{17}$

Yet Jenson does not merely define God by the events of the biblical narrative: rather, he makes the conceptual move to identify God with these events, ${ }^{18}$ thereby arguing that God's being is itself the historical event of 'what happens between Jesus and his Father in their Spirit'. ${ }^{19}$ Jenson justifies this move by arguing that, if God is only identified by, and not with, the resurrection, this identification would be merely a clue to God but not

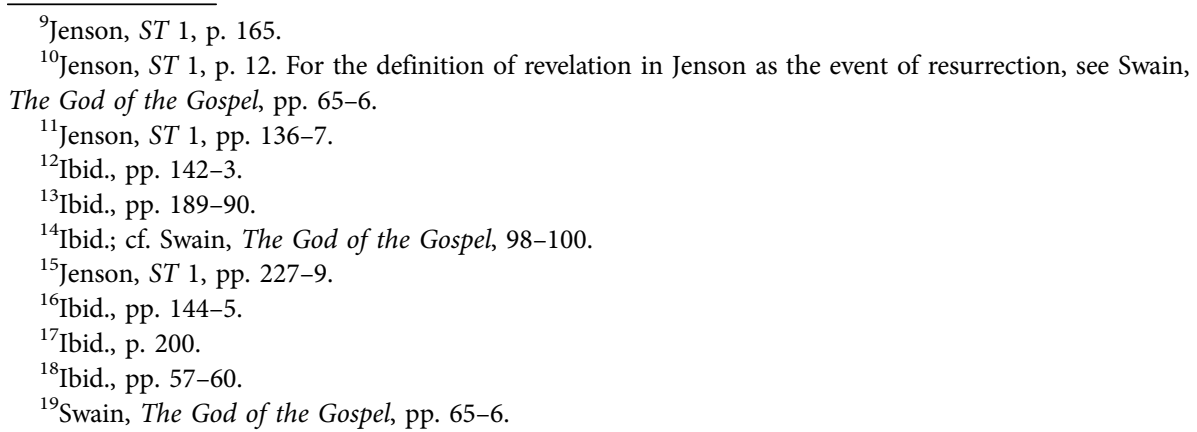


God himself. ${ }^{20}$ His methodology thus begins from the axiom that God is known with absolute reliability through Christ, and subsequently shapes his definition of God such that this axiom is substantiated, creating a divine ontology that is dictated by epistemology. Accordingly, for Jenson, 'because God is identified by a narrative, God is a narrative' and 'because it takes time to identify God, God is temporal'. ${ }^{21}$

The latter point is made explicit in Jenson's observation that the Greek conception of eternity as atemporality forces an unacceptable analogia temporalis into epistemology, since it follows that the temporal missions of Jesus and the Spirit are ultimately inapplicable to God and therefore cannot be internal to the divine being. ${ }^{22}$ Since divine atemporality dictates that the begetting of the Son must be timeless, it follows that he is begotten as a pre-existent atemporal Logos asarkos and only subsequently became the temporal Jesus of Nazareth, precluding us from identifying the second person of the Trinity with the historical figure simpliciter. ${ }^{23}$ Jenson thus summarises that, since revelation is inherently temporal, a theology with a timeless conception of God must view revelation as ultimately nothing more than outward symbolism. ${ }^{24}$ Conversely, by advocating an inherently temporal God, Jenson is able to assert that the content of revelation belongs to God's 'very deity', ${ }^{25}$ and is thus able to define the Trinity without qualification as 'simply the Father and the man Jesus and their Spirit as the Spirit of the believing community'. 26

In Jenson's methodology epistemology is identified with ontology, such that God becomes the very means by which God is known. This marks a clear break from conventional theological methodologies, in which a preformed doctrine of God, extrapolated from revelation, asserts its epistemological validity secondarily by appeal to how well it conforms with that revelation (and uses the extent to which it conforms as the metric to compare itself against competing doctrines). Yet, the principle of deriving ontology directly from epistemology stems from an important recognition: that the foremost concern of any theological system should be to secure the validity of the epistemological foundation on which its doctrines are built. To put the matter simply, any doctrine that is unable to demonstrate its reliability as knowledge of God - no matter how academically impressive - is ultimately inapplicable to the Christian faith. It follows from this that, in the construction of doctrine, epistemological reliability should take precedence over the content of the doctrine itself.

\section{God as event: Narratological metaphysics}

Jenson's system to secure the reliability of christological revelation operates by collapsing the categories of being and act to prevent a Deus absconditus in the form of static 'essence' behind God's temporal action in history. To provide metaphysical substantiation for his consequent identification of God with the event of the resurrection, Jenson transposes metaphysics from essentialist into narrative terms. ${ }^{27}$ Thus, he rejects

\footnotetext{
${ }^{20}$ Jenson, ST 1, pp. 57-60.

${ }^{21}$ Francesca Aran Murphy, God is Not a Story: Realism Revisited (Oxford: OUP, 2007), p. 268.

${ }^{22}$ Robert W. Jenson, The Triune Identity (Philadelphia: Fortress Press, 1982), pp. 138-9.

${ }^{23}$ Ibid., pp. $140-1$.

${ }^{24}$ Ibid., p. 26.

${ }^{25}$ Jenson, God After God, p. 162; Jenson, ST 1, pp. 48-9.

${ }^{26}$ Jenson, The Triune Identity, pp. 140-1.

${ }^{27}$ Murphy, God is Not a Story, p. 9.
} 
the Hellenistic definition of 'being' as ousia - a 'set of attributes one may be permanently relied on to exemplify' - in favour of the modern conception of 'being as history', ${ }^{28}$ defining God as 'the plot of his history'. ${ }^{29}$ As such, the divine being for Jenson denotes the common action of the three hypostases, from which it follows that 'God' is a narrative in which the three persons are inseparably united agents. By extension, God's unity is the coherence of this narrative, namely the fact that the actions of the three divine agents produce a unified whole. ${ }^{30}$

Since narrative constitutes 'the overarching genre by which Scripture identifies God', Jenson argues that God has 'a narrative identity'. That is, God's personal identity, like a story, 'unfolds according to a temporal structure' and is 'constituted by the outcome of narrative events', such that it is established from the end. ${ }^{31}$ For Jenson, God's being is thus teleological, with God not fully actualised 'apart from the telos of history', meaning that God's life is dictated by its outcome. ${ }^{32}$ This redefinition of identity in narrative terms provides the means to overcome the Deus absconditus remnant in Bruce McCormack's actualistic interpretation of Barth's doctrine of election, in the form of God's undetermined and unknowable being logically prior to his decision to be God-for-us. ${ }^{33}$ By replacing the protological determination that such a critique presupposes with teleological determination, Jenson argues that God can be exhaustively identified by the decision of election and thus as the God-for-us of revelation, since this is the divine identity at God's telos by which that identity is constituted. ${ }^{34}$

This treatment of the divine hypostases in strictly narrative terms leads Jenson to define them simply as 'relations subsisting in God', 35 and hence to argue that the three persons are their relations to one another. ${ }^{36}$ Jenson argues that the western church itself arrives at this conclusion, understanding the relations between each person, which constitute their identifying properties, as 'each identical with the one divine substance' in that they are themselves divine attributes and so name the divine substance (by virtue of divine simplicity). Thus, like the divine substance, they must subsist, possess attributes and stand as the subjects of actions. ${ }^{37}$ Jenson argues further that, since these relations are established in the economy of salvation, namely in Jesus' dependence on the Father and his sending of the Spirit, God's soteriological action ad extra exists 'on both sides of the God/creature line', and thus happen to God in se. He accordingly

\footnotetext{
${ }^{28}$ James, J. Buckley, 'Intimacy: The Character of Robert Jenson's Theology', in Colin E. Gunton (ed.), Trinity, Time and Church: A Response to the Theology of Robert W. Jenson (Grand Rapids, MI: William B. Eerdmans, 2000), p. 19.

${ }^{29}$ Jenson, God After God, pp. 106-8, 171-2.

${ }^{30}$ Murphy, God is Not a Story, p. 256; George Hunsinger, 'Robert Jenson's Systematic Theology: A Review Essay', Scottish Journal of Theology 55/2 (2002), pp. 194-5.

${ }^{31}$ Swain, The God of the Gospel, pp. 67-9.

${ }^{32}$ Hunsinger, 'Robert Jenson's Systematic Theology', pp. 181-2.

${ }^{33}$ While McCormack rejects the existence of an undetermined God temporally prior to election, he offers no explanation to refute the logical priority of such a God. Moreover, such logical priority follows from Barth's identification of election as a 'decision', which presupposes an antecedent agent by whom the decision was made. As can be seen from his repeated references to the Father as the subject of the decision to resurrect Jesus, it is clear that Jenson retains this sense of an antecedent, metaphysically undetermined God logically prior to the event of divine self-constitution.

${ }^{34}$ Swain, The God of the Gospel, pp. 73-4.

${ }^{35}$ Jenson, The Triune Identity, pp. 105-6.

${ }^{36}$ Jenson, 'Does God have Time?', pp. 192-3.

${ }^{37}$ Jenson, The Triune Identity, pp. 122-3.
} 
concludes that it is by just this temporal dynamic in the economy of salvation 'that the three are God'. ${ }^{38}$

\section{Divine freedom}

This indissoluble relationship between God and the economy of salvation raises, however, the question of how Jenson balances his concern to ensure the reliability of revelation with the Christian assertion of God's freedom in his acts ad extra. That is, since Jenson's theology sees the divine identity constituted by the event of the resurrection, this event becomes necessary for the divine being to have its particular character, rendering God dependent on creation for self-actualisation. If creation and redemption are in this way necessary to God's being, however, the gracious nature of these acts appears threatened, since grace presupposes that the acts are done freely. The conventional metric for this freedom consists in the possibility of 'counterfactuals' - hypothetical worlds in which God acts differently. Jenson's system seemingly forces one either to deny the possibility of such worlds (i.e. God could not have acted otherwise, or indeed have chosen not to act at all), thereby contradicting God's freedom and the gracious nature of creation and redemption; or to allow the possibility of such worlds but then to accept that the divine nature would be different in them, thereby undermining the reliability of the christological revelation in which this nature is revealed.

Counterfactual freedom is inapplicable to Jenson's theology, since it operates by positing precisely the distinction between God and revelation precluded by his rejection of the analogia temporalis. For Jenson, it is Barth's attempt to retain such counterfactual possibility that leads him to identify God with a pretemporal decision of election rather than directly with the divine action in the economy, leading to the fatal reintroduction of the analogia temporalis into his theology. Jenson's innovative solution to this problem is to reformulate the terms of the debate itself, rejecting the use of counterfactual possibility altogether as the metric for divine freedom.

Jenson argues that God's transcendence must in fact be understood in temporal terms, and hence that divine freedom over God's constitution in creation actually means God's futurity to what he already is in creation. ${ }^{39}$ Jenson thus points to his assertion that, as a narrative, God's identity is constituted from the end, meaning that God most truly exists in the future. For Jenson, this not only secures the reliability of revelation but also means that 'God is free over against the realized actualities of his trinitarian life with us, because he is always ahead of them'. As such, God can never be pre-empted (and so determined to be other than he wills) by any temporal occurrence. If the structure of the trinitarian life is thus divine futurity, then (Jenson argues) it is no longer necessary to posit God's freedom via counterfactual possibility that reduces the economic Trinity to a mere 'image' of the immanent Trinity, since divine futurity renders God inherently free (that is, not circumscribed by temporal events). ${ }^{40}$

Jenson provides metaphysical substantiation for this assertion through his doctrine of eternity. Parallel to Barth's notion that God makes time the form of divine eternity in the incarnation, ${ }^{41}$ Jenson argues that, in creation, God makes room in himself for

\footnotetext{
${ }^{38}$ Ibid., pp. $105-7$.

${ }^{39}$ Jenson, God After God, pp. 154-5.

${ }^{40}$ Ibid., pp. 173-4.

${ }^{41}$ Karl Barth, Die Kirchliche Dogmatik II/1 (Zurich: Evangelische Buchandlung Zollikon, 1940), p. 695.
} 
others, creating time and making it part of the triune being. ${ }^{42}$ Jenson accordingly follows Barth's assertion that past, present and future are in God, understanding this to mean that God makes up the structure of time, the three tenses of which are identical with the distinction between the Father, Son and Holy Spirit respectively. ${ }^{43}$

Since the structure of time is identified with God's being, it is a unified whole such that 'nothing in God recedes into the past or approaches from the future'. That is, while the distinctions between tenses correspond to the three persons of the Trinity, God's triune being nonetheless transcends these distinctions because the Trinity is, while three, nonetheless completely one. ${ }^{44}$ Thus, though the tenses are not simply collapsed into one another (as in a timeless eternity), neither are they isolated from one another, and it is this coinherence that defines eternity in contrast to time. ${ }^{45}$ This transcendence of temporal distinctions by the unity of the divine being can be understood through the concept of perichoresis, which denotes for Jenson the mutual work of the three persons in which every work 'is begun in the Father, accomplished in the Son, and perfected in the Spirit'. ${ }^{46}$

Thus, returning to Jenson's assertion that God is most truly himself in the future by virtue of the teleological constitution of the divine identity, Jenson argues that God is most accurately described as existing in the future. However, while this is true of all living personal beings in principle (e.g. human beings' identities become fully constituted only at the time of their death), the metaphysical 'difference between God and us is that he, as the Spirit, is his own future, ${ }^{47}$ and precisely this is the basis of the divine freedom from the constraint of the past. As such, Jenson argues that '[God's] eternity is that he can never be surpassed, never caught up with. He anticipates the future in the sense that however we press forward in time, we always find that God has already been there and is now ahead calling us on. ${ }^{48}$

Jenson supports this conclusion by appealing to the biblical account of the resurrection. He argues that the perichoresis that constitutes divine eternity is possible because the past and future are 'reconciled in the action and suffering of the Son'. However, since the resurrection is the act by which the crucified Jesus transcends time to become eternal, this event becomes, moreover, 'a constitutive element in the triune God's perichoretic unity', as the archetypal perichoretic transcendence of time. ${ }^{49}$ As such, it defines eternity, meaning that the character of the resurrection appearances provides vital information about the nature of this eternity. In this regard, Jenson notes the elusive quality of the experiences, arguing that they are elusive precisely because Jesus in these appearances belongs not to the present but the future, meaning by extension that the appearances are appearances of the future: promises of a final fulfilment that is 'now characterized as fulfilment precisely of the resurrection'. ${ }^{50}$ Accordingly, these appearances reveal that the nature of God's eternity is not timelessness, and thus immunity to the future, but rather 'his futurity to what already is'. ${ }^{51}$

\footnotetext{
${ }^{42}$ Jenson, ST 1, p. 226.

${ }^{43}$ Robert W. Jenson, The Works of God, vol. 2 of Systematic Theology [hereafter ST 2] (Oxford: OUP, 1999), p. 35.

${ }^{44}$ Hunsinger, 'Robert Jenson's Systematic Theology', p. 173.

${ }^{45}$ Jenson, 'Does God have Time?', pp. 194-5.

${ }^{46}$ Hunsinger, 'Robert Jenson's Systematic Theology', pp. 184-5.

${ }^{47}$ Jenson, ST 1, p. 143.

${ }^{48}$ Jenson, God After God, pp. 170-2.

${ }^{49}$ Hunsinger, 'Robert Jenson's Systematic Theology', pp. 184-5.

${ }^{50}$ Jenson, God After God, pp. 155-8.

${ }^{51}$ Ibid., p. 159.
} 


\section{The reduction of divine freedom}

Jenson's final discussion of counterfactual possibility as a metric for divine freedom is found in his article, 'Once More the Logos asarkos', where he argues that enquiry pertaining to the divine identity if God had not created or redeemed humanity is nonsensical and thus simply unanswerable. ${ }^{52}$ For Jenson, since God is defined as the event of the biblical narrative, questions regarding God's identity if that event had not taken place constitute a category error (namely the presupposition of the very essentialist metaphysic that he explicitly rejects, such that a distinct ousia may be posited independently of the event). However, it is a non sequitur for Jenson to claim on this basis that such questions are therefore not even a valid line of enquiry for Christian theology. Enquiry regarding counterfactual possibility concerns two central loci of Christian theology - the doctrine of God and theological anthropology - pertaining to the divine nature and freedom, and by extension to the grace of human existence and salvation; hence such enquiry is an appropriate subject of Christian reflection. Accordingly, Jenson's refusal to respond to these questions, even if they are incompatible with his metaphysics, would constitute a substantial deficiency of his argument, if it can be demonstrated that the ability to make sense of counterfactuals is essential to the functioning his theological system as a whole.

It is the contention of article that this is indeed the case for Jenson, because the freedom he proposes in the place of counterfactual possibility in the hopes of rendering such questions otiose is unable to perform the same function as counterfactual possibility. That is, Jenson's conception of freedom cannot secure the gracious nature of divine action ad extra, since the event to which these actions correlate is identified with God. The classical tradition's assertion that the God-creation relationship is only constitutive on the side of creation is designed to ensure that, while God's decision to save humanity presupposes creation, this event is nonetheless extrinsic to the divine being and can thus still be gracious. In Jenson's system, by contrast, since God's decision to redeem humanity is at the same time the decision to constitute God's identity as the event of that redemption, the intrinsically directed aspect of this desire threatens to render redemption a necessary prerequisite to fulfil in the course of divine selfrealisation. The metric of freedom as futurity is unable to overcome this problem, since Jenson clearly argues for the ontological reality of God's past and future in his identification of them with the Father and the Spirit respectively, with perichoresis meaning that God possesses past, present and future simultaneously. As such, God's ultimate future identity does have a concrete reality. Moreover, since Jenson argues that the whither of the divine life is also the whither of creation (the eschaton), it follows that this concrete future identity is inseparable from, and thus ultimately dependent on, creation. $^{53}$

Most significantly, however, Jenson does not merely portray God as dependent on history but, by defining the divine being directly in terms of the biblical narrative, renders God dependent on the language by which history is codified into narrative, and thus ultimately dependent on human thought. As Murphy correctly observes, the development of Barth's notion that 'God is known only in God and by God's act' into Jenson's claim that God can only be known in the biblical story itself means that the biblical story absorbs the divine being, such that God can only be comprehended in

\footnotetext{
${ }^{52}$ Robert W. Jenson, 'Once More the Logos asarkos', International Journal of Systematic Theology 13/2 (2011), p. 131.

${ }^{53}$ 'Does God have Time?', p. 199.
} 
relation to the economy of salvation described in the biblical narrative, and thus 'in relation to our language'. This means that God cannot transcend the divine relationship with humanity explicated in the Bible, because language is understood necessarily to have meaning, and thus to require an interlocutor for whom it has this meaning. ${ }^{54}$ However, if the divine being is dependent on the interlocutor for reality, God is inherently related to the human mind, and is so reduced to an idolatrous projection of humanity.

\section{The reintroduction of the analogia temporalis}

Jenson attempts to ensure the reliability of temporal revelation through the categories of being and act, collapsing the two categories to preclude any gap that could undermine revelation by suggesting an eternal level above it. However, in so doing he denies counterfactual possibility, which presupposes just such a gap between the eternal God and revelation such that God could act differently in time (viz., by altering the content of revelation) while remaining the same God. Accordingly, the collapse of the two categories to assert the reliability of the God of revelation naturally leads to the re-emergence of an eternal reality above revelation to compensate for the consequent loss of freedom, and hence the return to an epistemology mediated through the analogia temporalis.

This re-emergence is seen immediately after Jenson identifies God with the events of revelation, in his attempted solutions to two negative implications arising from this theological move. The first implication is that, if the divine being is determined by the economy of salvation, the fact that the plot of this action is dictated by the fall suggests that if humanity did not rebel against God, the divine being would be different, rendering God dependent on human actions. To avoid this implication, Jenson, following Barth, denies the possibility of the counterfactual, arguing that humanity was always destined to sin and hence that the incarnation would always have taken place, and with precisely the same content of redemption. ${ }^{55}$ Jenson supports this argument on the basis that Ephesians and Colossians not only assert that the incarnation was set forth prior to creation and indissoluble with it, but in doing so interweave references to humanity's redemption through his death, making the content of the incarnation logically prior to creation. ${ }^{56}$ Jenson thus argues that the historical economy of salvation was God's eternal plan rather than simply his 'reaction to human sin', and hence that God's being has its sole determinant in the divine will. ${ }^{57}$

The second implication is that Jenson's exegesis of Romans 1:4-5 - that Jesus is determined as the Son solely by virtue of the resurrection - suggests that the divine identity is ultimately serendipitous, again denying God sole agency in his selfdetermination. That is, if Jesus was initially a normal human being who simply 'happened to' conform to the divine life and thereby became the second identity of God, the possibility existed for the divine identity to have been constituted at a different time or in a different way. Jenson's rhetoric supports this implication, speaking of multiple 'candidates' to be God's self-identifying Word, with the Father only ultimately settling on Jesus of Nazareth for this role in the decision to resurrect him. Nonetheless,

\footnotetext{
${ }^{54}$ Murphy, God is Not a Story, p. 120.

${ }^{55}$ Jenson, ST 1, pp. 72-3.

${ }^{56}$ Ibid., p. 73.

${ }^{57}$ Anne H. Verhoef, 'The Relation between Creation and Salvation in the Trinitarian Theology of Robert Jenson', HTS Teologiese Studies 69/1 (2013), p. 4.
} 
Jenson denies this implication of Romans 1:4-5, arguing that Paul does not preclude the possibility of Jesus being the Son prior to the resurrection here, since he simply gives no reference to the origin of the Son at all. ${ }^{58}$

That is, Jenson denies that Jesus simply 'happened to' become the second person of the Trinity by asserting that he in some sense pre-existed in this role. Explaining how he can nonetheless sustain his identification of the second person of the Trinity with the historical Jesus Christ simpliciter, Jenson argues that the Son's antecedence of his physical birth does not constitute 'the addition of the human Jesus' to a pre-existing, preformed Logos asarkos, since Jesus rather pre-existed his human birth precisely as Jesus. ${ }^{59}$ Jenson interprets this anticipatory pre-existence through his analysis of the theology of Irenaeus, whom he understands to have secured God's eternal triunity by arguing that the economy of salvation in which this triune being is grounded pre-existed its historical occurrence as God's eternal pre-determination that humanity would be saved by the Son. ${ }^{60}$ By advocating this solution, Jenson reveals that he likewise understands Jesus' pre-existence through the motif of the Father's eternal intention. In short, since Jesus' sonship is constituted by his resurrection, he pre-exists as the Father's preexisting decision to resurrect him. ${ }^{61}$

Jenson therefore denies both charges that the divine identity is dictated by factors external to God's agency - whether the fall or serendipity - by asserting the eternal intention of Jesus' existence and resurrection, using this same assertion to explain references to Jesus' pre-existence in the New Testament while maintaining his identification of the second person of the Trinity with Jesus Christ simpliciter. In so doing, however, Jenson undermines one of his key divergences from Barth's theology - the relocation of the decision of election from primordial time to the event of the resurrection. As a result, Swain is able to characterise Jenson's doctrine of election correctly in terms equally applicable to Barth, namely as 'God's eternal decision ... to exist as the Father of the man Jesus'. ${ }^{62}$

A tension thus exists at the heart of Jenson's theology between time and eternity (namely, between the time of revelation and primordial time) as the location of the divine decision of election by which God's being is constituted, with his theology seeming to demand at least some form of election at the beginning of time akin to that found in Barth's theology to be coherent. While Jenson may argue that this primordial decision is only ultimately concretised in the biblical narrative, this constitutes merely a shift of focus from Barth rather than a qualitative divergence from him. As a result, Jenson falls subject to the very critique he employs against Barth: namely, that his theology likewise retains the 'Platonic' analogy of time as the image of eternity, reducing revelation to the mere temporal unfolding of a primordial archetype in the form of God's predetermined decision of election. As in Barth's theology then, the analogia temporalis is reintroduced as the reader is drawn back to eternity to understand the basic decision by which the divine nature is constituted, and thus the highest reality of God.

The same fundamental tension is present in relation to Jenson's use of narrative, with the collapse of the economic and immanent trinities leading to an emphasis on the narrative distinction between the three persons found at the economic level that can no longer be offset by an emphasis on unity at the immanent level (namely, that

\footnotetext{
${ }^{58}$ Jenson, ST 1, pp. 142-3.

${ }^{59}$ Jenson, 'Once More the Logos asarkos', pp. 130-1.

${ }^{60}$ Jenson, The Triune Identity, p. 70.

${ }^{61}$ Hunsinger, 'Robert Jenson's Systematic Theology', p. 173.

${ }^{62}$ Swain, The God of the Gospel, pp. 101-3.
} 
the three persons possess the same divine substance). Murphy argues that this focus on revelation and corresponding accentuation of difference naturally implies a higher Unity which enables us to take account of it', thereby positing a more ultimate God behind revelation and ironically leading to the very modalism this emphasis is designed to counter. ${ }^{63}$ She thus argues that, just as pagan mythology envisions 'a single rule beyond the many gods', Jenson portrays 'story' as the one true God behind the three persons, acting as fate controlling their fortunes. ${ }^{64}$ Murphy's thesis is arguably proven right when one turns to examine Jenson's attempts to assert divine freedom by denying God's dependence on human agency. Here Jenson argues that, while the dramatic nature of the biblical narrative presupposes the possibility of various alternatives, the events nonetheless had to happen the way they historically did. ${ }^{65}$ This means both that Jesus was always fated to submit to the divine will in Gethsemane, and that humanity was always destined to fall.

Finally, an eternal reality above revelation is most obviously seen in the repeated references to counterfactual possibility in Jenson's theology, which, as aforementioned, presupposes the distinction between God and his action ad extra. Despite claiming that counterfactual freedom is rendered otiose by divine futurity, until 'Once More the Logos asarkos' Jenson consistently referred to God's possession of just such freedom, emphasising the need to affirm God's ability to have established the same self-identity in a different way. Jenson nonetheless attempts to avoid the implication of an eternal reality beyond revelation through appeal to divine mystery, arguing that, while one can simply state the basic possibility that the divine identity would have been the same if God had acted otherwise, one cannot state anything whatsoever about how this could be the case. $^{66}$

When pressed, however, Jenson is ultimately forced to admit that God could not be exactly the same had he not created, since the second person would in this case be unincarnate rather than the historical Jesus simpliciter. ${ }^{67}$ His assertion that God would nonetheless still somehow be the very same God that he is despite this caveat demonstrates that Jenson in fact believes that the God of counterfactual possibility would have the same identity as the God constituted in the economy of salvation, as long as the former would merely perfectly mirror the latter. Thus, despite Jenson's claims that the economic Trinity just is the immanent Trinity and vice versa, his advocation of counterfactual possibility suggests a distinction between these two levels, such that God can be the very same God that he is without the economy of salvation and thus without the economic Trinity. Accordingly, as in the classical tradition, Jenson's argument implies that the divine identity exists independently of the biblical narrative, thus implicitly reintroducing something like Barth's analogia temporalis as the means by which this narrative provides knowledge of God's ultimate reality.

\section{Evaluation: The collapse of being and act}

Jenson's theology constitutes a daringly innovative attempt to resolve the centuries-old stalemate in which the epistemology-freedom debate has found itself. Jenson identifies

\footnotetext{
${ }^{63}$ Murphy, God is Not a Story, pp. 261-2, 238.

${ }^{64}$ Ibid., p. 254.

${ }^{65}$ Jenson, ST 1, pp. 47-8.

${ }^{66}$ Ibid., p. 65.

${ }^{67}$ Ibid., pp. 141-2.
} 
God with the event of the resurrection, denying any metaphysical reality beyond God's temporal action that might relegate the ontological significance of revelation by mediating it through the analogia temporalis. He thus collapses the categories of being and act, transposing metaphysics from essentialist to narrative terms to define God as one perfectly mutual act with three subsistent relations, and consequently as the story of that act as codified in the biblical narrative. However, the true genius of Jenson's solution is that his identification of God with narrative at the same time grounds his assertion of divine freedom ad extra. In contrast to Barth's solution of creating a gap between the divine self-determination and action ad extra, Jenson transforms the terms of the debate itself, arguing that, since the identity of a narrative is determined from its end, so too is God's identity determined from the eschaton, meaning that God most truly exists in the future. He thus argues that God is inherently free from the conditions of the past, dispensing with the need to posit counterfactual freedom.

Nonetheless, this article has demonstrated that Jenson's reformulation of the metric for freedom as divine futurity is unable to serve the same function provided by counterfactual freedom, namely to ensure that divine action ad extra is extrinsic to God and thereby to prevent God from being rendered dependent on creation for selfactualisation. While the differentiation between God and the economy of salvation presupposed by enquiry into counterfactual possibility may be categorically incompatible with Jenson's identification of the divine being with this economy, we have argued that such enquiry is nonetheless of key importance in Christian theology, such that Jenson's inability to respond to it reflects a deficiency in his argument. Moreover, this article has argued that the God of Jenson's theology is accordingly dependent not only on history but, since he is defined directly in terms of the biblical narrative, also on language and thus the human interlocutor for whom this language has meaning. God therefore appears to become inherently related to the human mind, suggesting the very Feuerbachian idolatry that Jenson's system takes as its starting point to preclude.

Such critique is indissolubly linked with the kernel of Jenson's proposal to ensure the reliability of revelation, namely the collapse of the categories of being and act. Since God's freedom in action ad extra presupposes transcendence over those actions, this collapse is self-defeating in Jenson's theology, as the more insistently he attempts to collapse the two categories, the more tenaciously a higher (eternal) reality above the God of revelation re-emerges to cauterise the implied loss of freedom. This is found in three forms. First, it is found in Jenson's appeal to the pre-existence of Jesus Christ and the economy of salvation as the Father's eternal intention, creating a tension between primal and revelation time as the location of God's basic decision of election, and thus ultimately committing Jenson to the very same 'Platonic' analogy that he criticises in Barth's theology. Second, it is found as a narrative tension at multiple points in which Jenson wishes to deny God's loss of agency in the economy of salvation and thus in the constitution of his being. This correlates with Murphy's identification of fate as the one true God in Jenson's theology to counteract the tritheism implied by his accentuation of the narrative distinction of the three persons. Third, it is seen in Jenson's seeming own recognition of the importance of asserting God's counterfactual freedom despite divine futurity in his repeated references to this freedom, which he himself ultimately admits presupposes a distinction between the divine identity and the economy of salvation.

It is thus clear that the analogia temporalis has an essential function in theological epistemology as long as the Christian faith continues to assert the gracious nature of God's acts ad extra. Accordingly, using Jenson's theology as a case-study, the issues 
highlighted in this article suggest that the attempt to secure the reliability of revelation via the metaphysical identification of being and act is misguided. While it appears theology must accept the use of some version of the analogia temporalis, therefore, it is not clear that it must accept the binary between absolute truth and falsity that Jenson's rejection of this analogy presupposes. That is, one must ask why positing a reality of God behind revelation means, as Jenson puts it, 'declaring the story simply to be false'? While Jenson explains that this use of analogy implies a deeper reality of God, he does not explain why it necessarily follows that this reality is unknowable. Rather, he inexplicably conflates the use of the analogia temporalis with equivocation, when in fact the former is by definition distinct from the latter, since it presupposes that the deeper reality to which the analogy points is truly and reliably disclosed in it. Moreover, epistemology mediated through the analogia temporalis is surely validated in 1 Corinthians 13:12, with its reference to the present knowledge of God as a 'reflection' of the ultimate divine reality. Even if Jenson interprets this passage to refer to the limitation of human understanding, it is not obvious why this would not entail the very same problems he identifies with the analogia temporalis.

Yet when turning to consider this form of analogy, it turns out that the framework already exists to combine the two facets of the epistemology-freedom debate precisely as it turns to consider the property most closely associated with the divine being: love. This most essential identification of God is consequently the very thing Jenson's system is unable to secure, since divine love is established as a direct corollary of the assertion of God's counterfactual freedom, whereby creation and salvation are secured as unnecessary to the divine being, and therefore - as pure grace - essentially acts of love. Jenson is correct to identify the solution to the debate not through a compromise of the reliability of revelation and/or divine freedom, but rather through combining these two basic tenets of Christian theology in the faith that all theological dialectics must ultimately be subsumed into the divine unity. However, it is the assertion of this article that we develop this insight going forward by searching for such a combination not in the abandonment of the analogia temporalis but in a more robust usage of it. While this tension may not be fully resolved until the eschaton when God is seen 'face to face' (1 Cor 13:12), theology can take as its starting point the recognition that God's freedom from creation is at the same time the proclamation that 'God is love' (1 John 4:8).

Cite this article: Garton AD (2020). Reliable knowledge, true freedom: The remnant of the analogia temporalis in the theology of Robert Jenson and its implications for the epistemology-freedom debate. Scottish Journal of Theology 73, 239-251. https://doi.org/10.1017/S0036930620000356 